\title{
Review
}

\section{Lipid peroxidation and cell cycle signaling: 4-hydroxynonenal, a key molecule in stress mediated signaling ${ }^{\star}$}

\author{
Yusong Yang ${ }^{1}$, Rajendra Sharma ${ }^{1}$, Abha Sharma ${ }^{1}$, Sanjay Awasthi ${ }^{2}$ and \\ Yogesh C. Awasthi ${ }^{1 凶}$ \\ ${ }^{1}$ Department of Human Biological Chemistry and Genetics, University of Texas Medical Branch, \\ Galveston, TX 77550; ${ }^{2}$ Department of Chemistry and Biochemistry, University of Texas at \\ Arlington, Arlington, TX 76019, U.S.A.
}

Received: 07 April, 2003; revised: 05 May, 2003; accepted: 12 May, 2003

Key words: apoptosis, 4-hydroxynonenal, glutathione $S$-transferase, RLIP76, RalBP1, cell cycle signaling

Role of lipid peroxidation products, particularly 4-hydroxynonenal (4-HNE) in cell cycle signaling is becoming increasingly clear. In this article, recent studies suggesting an important role of 4-HNE in stress mediated signaling for apoptosis are critically evaluated. Evidence demonstrating the modulation of UV, oxidative stress, and chemical stress mediated apoptosis by blocking lipid peroxidation by the $\alpha$-class glutathione S-transferases (GSTs) is presented which suggest an important role of these enzymes in protection against oxidative stress and a role of lipid peroxidation products in stress mediated signaling. Overexpression of 4-HNE metabolizing GSTs

\footnotetext{
This work was supported in part by NIH grants: GM 32304 (YCA), EY04396 (YCA), and CA 77495 (SA).

${ }^{凶}$ Yogesh C. Awasthi, Ph.D., 551 Basic Science Building, Department of Human Biological Chemistry and Genetics, University of Texas Medical Branch, Galveston, TX 77555-0647 U.S.A.; tel.: (1) 409772 2735; fax: (1) 409772 6603; e-mail: ycawasth@utmb.edu

Abbreviations: AP-1, the transcription factor activator protein; CAT, catalase; CBAs, chain-breaking antioxidants; CU-OOH, cumene hydroperoxide; $\mathrm{CPLA}_{2}$, cytosolic phospholipase $\mathrm{A}_{2}$; FA-OOH, fatty acid hydroperoxides; HLE B-3 cells, human lens epithelial cells; 4-HNE, 4-hydroxynonenal; 5-HPETE, 5-hydroperoxyeicosatetraenoic acid; 13S-HPODE, 13S-hydroperoxy-9Z,11E-octadecadienoic acid; GSH, glutathione (reduced form); GPxs, glutathione peroxidases; GS-HNE, glutathione conjugate of 4-HNE; GST, glutathione $S$-transferase; K562 cells, human erythroleukemia cells; LOOH, lipid hydroperoxide; MAPK, mitogen activated protein kinases; $\mathrm{NF} \kappa$-B, nuclear factor kappa B; PC-OOH, phosphatidylcholine hydroperoxide; PL-OOH, phospholipid hydroperoxides; PUFA, polyunsaturated fatty acids; RLIP76, $76 \mathrm{kDa}$ Ral-binding GTPase activating protein (RalBP1); ROS, reactive oxygen species; $\mathrm{SAPK} / \mathrm{JNK}$, stress activated protein kinase/c-Jun N-terminal kinase; SOD, superoxide dismuatase; t-BHP, tert-butyl hydroperoxide.
} 
(mGSTA4-4, hGSTA4-4, or hGST5.8) protects cells against 4-HNE, oxidative stress $\left(\mathrm{H}_{2} \mathrm{O}_{2}\right.$ or xanthine/xanthine oxidase), and UV-A mediated apoptosis by blocking JNK and caspase activation suggesting a role of $4-\mathrm{HNE}$ in the mechanisms of apoptosis caused by these stress factors. The intracellular concentration of 4-HNE appears to be crucial for the nature of cell cycle signaling and may be a determinant for the signaling for differentiation, proliferation, transformation, or apoptosis. The intracellular concentrations of 4-HNE are regulated through a coordinated action of GSTs (GSTA4-4 and hGST5.8) which conjugate 4-HNE to GSH to form the conjugate (GS-HNE) and the transporter $76 \mathrm{kDa}$ Ral-binding GTPase activating protein (RLIP76), which catalyze ATP-dependent transport of GS-HNE. A mild stress caused by heat, UV-A, or $\mathrm{H}_{2} \mathrm{O}_{2}$ with no apparent effect on the cells in culture causes a rapid, transient induction of hGST5.8 and RLIP76. These stress preconditioned cells acquire ability to metabolize and exclude 4-HNE at an accelerated pace and acquire relative resistance to apoptosis by UV and oxidative stress as compared to unconditioned control cells. This resistance of stress preconditioned cells can be abrogated by coating the cells with anti-RLIP76 antibodies which block the transport of GS-HNE. These studies and previous reports discussed in this article strongly suggest a key role of 4-HNE in stress mediated signaling.

It has been known for a long time that reactive oxygen species (ROS) and the lipid peroxidation products formed due to oxidative stress are cytotoxic. Recent studies suggest that both, ROS and lipid peroxidation products, are also involved in the intracellular signaling mechanisms which determine the cell's final fate. Intracellular levels of ROS may be crucial for determining whether the cells undergo differentiation, proliferation, or apoptosis because it has been shown that at low concentrations, $\mathrm{H}_{2} \mathrm{O}_{2}$ induces mitosis in fibroblasts, while at relatively higher concentrations, it causes a transient cell growth arrest by inducing the expression of gadd45, gadd153, and adapt15 genes (Crawford et al., 1996). Even further higher concentrations permanently damage the cells perhaps due to the combined effects of apoptosis and necrosis (Chen \& Ames, 1994; Davies, 2000). Likewise, it has been shown that while higher levels of superoxide anions $\left(\mathrm{O}_{2}{ }^{-}\right)$are toxic, low levels of $\mathrm{O}_{2}{ }^{-}$elicit cellular proliferation in a variety of cells including fibroblasts, amnion cells, and colonic epithelial cells (Murrell et al., 1990; Ikebuchi et al., 1991; Craven et al., 1986). Interestingly, lipid peroxidation products, particularly 4-HNE, also affect signaling mechanisms in a concentration dependent manner. It has been shown that while low levels of 4-HNE promote proliferation (Ruef et al., 1998; Cheng et al., 1999), at higher concentrations it induces differentiation and apoptosis (Dianzani et al., 1999; Cheng et al., 1999; 2001a; 2001b; Kruman et al.,1997; Soh et al., 2000). Since $\mathrm{O}_{2}{ }^{-}$and $\mathrm{H}_{2} \mathrm{O}_{2}$ are known to cause membrane lipid peroxidation through Fenton reaction $\left(\mathrm{H}_{2} \mathrm{O}_{2}+\mathrm{Fe}^{2+}={ }^{\bullet} \mathrm{OH}+\mathrm{Fe}^{3+}\right)$, it is conceivable that $\mathrm{O}_{2}{ }^{-}$and $\mathrm{H}_{2} \mathrm{O}_{2}$ mediated cellular signaling may indeed be transduced at least in part, through lipid peroxidation products. This idea finds support from the studies demonstrating that lipid hydroperoxides $(\mathrm{LOOH})$ and 4-HNE per se can affect intracellular signaling mechanisms (Leonarduzzi et al., 2000; Uchida et al., 1999).

It is possible that the stress mediated signaling for apoptosis in general may involve lipid peroxidation products because most of the stress causing agents, e.g., oxidants, heat shock, UV irradiation, and serum starvation etc., invariably induce lipid peroxidation. Recent studies in our laboratory strongly support this idea and suggest that stress mediated cellular signaling is at least in part due to lipid peroxidation products, 4-HNE in particular (Yang et al., 2001; Cheng et al., 2001a; 2001b). These studies show that stress (UV, heat, oxidative, or chemical) mediated signaling in various cells can be modulated by manipulating the lipid peroxidation levels resulting from the stress. These studies also suggest 
that the $\alpha$-class GSTs may be the major determinants of the intracellular concentrations of lipid peroxidation products and that these enzymes can modulate stress mediated signaling. In this review, we have summarized these studies against the back drop of our current understanding of the role of lipid peroxidation products in signaling processes. Furthermore, we have evaluated the physiological roles of GSTs, and a newly discovered transporter RLIP76 (Awasthi et al., 2000; 2001), in regulating the intracellular concentrations of 4-HNE.

\section{REACTIVE OXYGEN SPECIES AND LIPID PEROXIDATION}

In aerobic organisms, ROS including $\mathrm{O}_{2}{ }^{-}$, $\mathrm{H}_{2} \mathrm{O}_{2}$, hydroxyl radical $\left({ }^{\bullet} \mathrm{OH}\right)$, and nitric oxide/peroxynitrate $\left(\mathrm{NO} / \mathrm{ONOO}^{-}\right)$are continually generated in cells via various endogenous and exogenous sources such as mitochondrial age-related disease such as Alzheimer's disease, cataract, atherosclerosis, Parkinson's disease (Bhuyan et al., 1986; Witztum, 1994; Markesbery \& Lovell, 1997; Yoritaka et al., 1996), etc. To detoxify ROS, mammalian cells have developed elaborate defense mechanisms. Oxidative stress occurs in the cells as a consequence of an imbalance between the pro-oxidant/antioxidant systems (Sies, 1985). Oxidative stress causes damage to cellular macromolecules such as nucleic acids, proteins, and lipids. Among these targets, the peroxidation of lipids is particularly more damaging because the formation of lipid peroxidation products leads to a facile propagation of free radical reactions. Abstraction of a hydrogen atom from the polyunsaturated fatty acid (PUFA) moiety of membrane phospholipids initiates the process of lipid peroxidation (Fig. 1). The resulting alkyl radical may rearrange to a more stable conjugated diene, which enters the autocatalytic lipid peroxidation cascade. Phospholipid hydro-

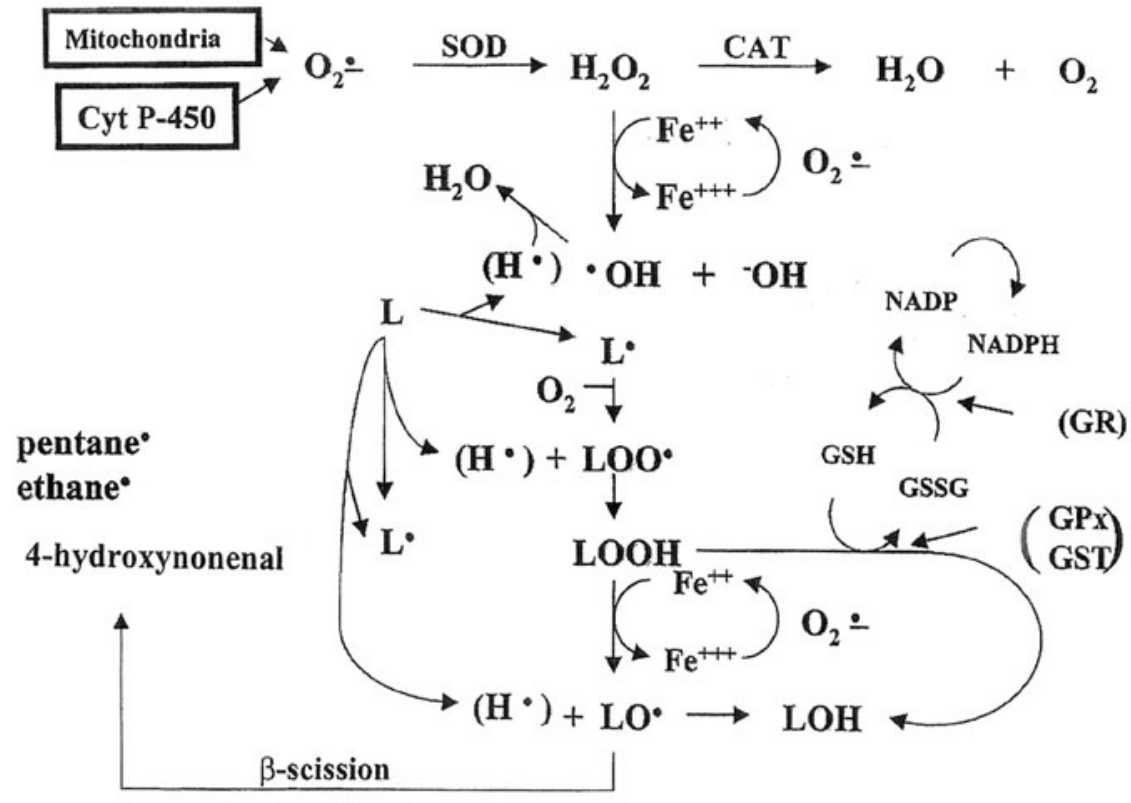

Figure 1. Lipid peroxidation, an autocatalytic chain process.

electron transport chain, biotransformation of various xenobiotics and drugs, inflammation, UV and ionic irradiation, and nitric oxide synthetase (Ames et al., 1993; Beckman \& Koppenol, 1996). ROS are toxic and are known to be involved in the etiology of peroxides (PL-OOH) and fatty acid hydroperoxides (FA-OOH) constitute the major portion of the lipid peroxidation products and can propagate lipid peroxidation chain reactions. The fatty acid carbon chain may also be spontaneously cleaved ( $\beta$-scission) during lipid 
peroxidation, yielding a variety of highly reactive compounds, including pentane and ethane radicals, and the $\alpha, \beta$-unsaturated aldehydes. In particular 4 -HNE, the major $\alpha, \beta$-unsaturated aldehyde formed by the degradation of both $\omega-3$ and $\omega-6$ PUFA during lipid peroxidation is fairly stable and present in relatively higher amounts in biological membranes under the conditions of oxidative stress (Esterbauer et al., 1991).

\section{DEFENSE AGAINST INTRACELLULAR LIPID PEROXIDATION}

In mammalian cells, there are two tiers of antioxidant defense mechanisms against ROS mediated lipid peroxidation. Low molecular mass compounds which act primarily against peroxyl radicals involved in radical propagation provide first line of defense against lipid peroxidation. These compounds referred as "chain-breaking antioxidants (CBAs)" can terminate the propagation of free radical mediated reactions and interrupt the autocatalytic chain reaction of lipid peroxidation (Acworth et al., 1997). The main cellular CBAs include $\alpha$-tocopherol, ascorbic acid, glutathione (GSH), uric acid, carotenoids, ubiquinone, and polyphenols, etc. (Acworth et al., 1997). Among these, GSH is particularly important because it also serves as the substrate for the two major antioxidant enzyme systems, glutathione peroxidases (GPxs) and GSTs.

The antioxidant enzymes constitute the second line of defenses which provide a variety of primary and secondary defenses against oxidative stress. Primary antioxidant enzymes are mainly preventive and these enzymes such as superoxide dismuatase (SOD), catalase (CAT), and GPxs can decompose ROS and prevent the damage to cellular constituents and initiation of lipid peroxidation. Secondary defenses typically involve excision or repair of any lesions caused by ROS. In the event of ROS induced lipid peroxidation, secondary defense enzymes are involved in the removal of $\mathrm{LOOH}$ to terminate the autocatalytic chain of lipid peroxidation and protect membranes. GPxs and GSTs which catalyze GSH-dependent reduction of $\mathrm{LOOH}$ (PL-OOH and FA-OOH) through their peroxidase activity are the major secondary defenses to guard against ROS-induced lipid peroxidation. So far, four selenium-dependent GPx isoenzymes have been characterized in mammalian tissues (Awasthi et al., 1975; Chu et al., 1993; Takahashi et al., 1987; Ursini et al., 1985). Among these enzymes, GPx-1, GPx-2, and GPx-3 are primarily involved in the reduction of $\mathrm{H}_{2} \mathrm{O}_{2}$ and $\mathrm{FA}-\mathrm{OOH}$, whereas GPx-4 displays activity towards PL-OOH and cholesterol hydroperoxides (Thomas et al., 1990).

\section{ROLE OF GLUTATHIONE $S$-TRANSFERASES IN THE REGULATION OF LIPID HYDROPEROXIDE LEVELS}

In addition to selenium-dependent GPxs, the selenium-independent GPx activity of the $\alpha$-class GSTs is also involved in the reduction of LOOH. A GPx activity designated as GPx-II was first described in rat liver (Lawrence \& Burk, 1976) and was later shown to be catalyzed by GSTs (Prohaska \& Ganther, 1976). Subsequently, it was shown that in human liver, the GPx-II activity was not expressed by all isoenzymes of the cytosolic GSTs but was confined only to the $\alpha$-class GSTs (Awasthi et al., 1980; Singhal et al., 1992). Comprehensive reviews on GSTs are available (Mannervik \& Danielson, 1988; Hayes \& Pulford, 1995; Awasthi et al., 1994) and a table of $\alpha$-class GSTs with relevance to lipid peroxidation products is provided (Table 1) with their currently used designations (Mannervik et al., 1992).

Earlier studies (Awasthi et al., 1980) used the organic hydroperoxides such as cumene hydroperoxide (CU-OOH) and tert-butyl hydroperoxide (t-BHP) as the substrates for 
GPx-II activity of GSTs and provided no information on the physiological role of GSTs in the GSH-dependent reduction of the $\mathrm{LOOH}$ generated during lipid peroxidation. Studies in our laboratory have shown that human $\alpha$-class GST isoenzymes can effectively reduce both FA-OOH and PL-OOH (Fig. 2) through their selenium-independent GPx activity (Singhal et al., 1992; Zhao et al., 1999; Yang et $a l ., 2001)$. The $\alpha$-class GST isoenzymes of other mammalian species also display this activity. For example, the $\alpha$-class GSTs isolated from rat skin catalyze the reduction of choles- lipase $\mathrm{A}_{2}$ mediated release of FA- $\mathrm{OOH}$ from the peroxidized membrane phospholipids.

The contribution of the $\alpha$-class GSTs in the reduction of $\mathrm{PL}-\mathrm{OOH}$ in various human and rat tissues has been measured by immunoprecipitation studies using highly specific polyclonal antibodies against the $\alpha$-class GSTs (Yang et al., 2001; 2002b). These studies indicate that in liver and testes of normal humans and rats, about $50-60 \%$ of total GPx activity towards PL-OOH is contributed by the $\alpha$-class GSTs. It appears that a higher expression of the $\alpha$-class GSTs in these tissues

Table 1. GST isoenzymes involved in detoxification of lipid peroxidation products

\begin{tabular}{llll}
\hline Enzyme name* & Species & Class & Preferred substrate** $^{* *}$ \\
\hline hGSTA1-1 and hGSTA2-2 & human & Alpha & PL-OOH, FA-OOH \\
hGSTA4-4 & human & Alpha & $4-\mathrm{HNE}$ \\
hGST5.8 & human & Alpha & $4-\mathrm{HNE}$ \\
mGSTA4-4 & mouse & Alpha & $4-\mathrm{HNE}$ \\
rGSTA4-4 & rat & Alpha & $4-\mathrm{HNE}$ \\
\hline
\end{tabular}

*In this nomenclature (Mannervik et al., 1992), lowercase letter identifies species while uppercase letter identifies the class (alpha). Nomenclature of hGST5.8 is based on its pI value of 5.8. mGSTA4-4, hGST5.8, and rGSTA4-4 are immunologically similar but distinct from hGSTA1-1, hGSTA2-2, hGSTA3-3 and hGSTA4-4. **PL-OOH, phospholipid hydroperoxides; FA-OOH, fatty acid hydroperoxides; 4-HNE, 4-hydroxynonenal.

terol hydroperoxides (Hiratsuka et al., 1997) and the $\alpha$-class GSTs of rat and mouse liver can utilize lipid peroxidation products as substrates (Zimniak et al., 1994; Yang et al., 2002a; 2002b). The GPx activity of human $\alpha$-class GSTs towards PL-OOH has been confirmed by studies with the recombinant GST isoenzymes, hGSTA1-1 and hGSTA2-2 (Zhao et al., 1999; Yang et al., 2001). More importantly, recent studies in our laboratory have demonstrated that hGSTA1-1 and hGSTA2-2 can reduce $\mathrm{PL}-\mathrm{OOH}$ present in biological membranes which strongly suggest that these enzymes can arrest membrane lipid peroxidation in situ (Yang 2001; 2002a; 2002b). Thus contrary to earlier suggestions (Tan et $a l ., 1984)$, the $\alpha$-class GSTs can reduce membrane PL-OOH without requiring phospho- provides these vital organs an added protection against ROS induced lipid peroxidation. In the liver of GPx-1 knockout mice, GPx activity towards $\mathrm{H}_{2} \mathrm{O}_{2}$ is decreased by about $90 \%$ but there is no significant decrease in the GPx activity towards PL-OOH. Kinetic studies using recombinant $\alpha$-class GSTs and the GSTs purified from human lung and human lens epithelial cells show that $K_{\mathrm{m}}$ of these enzymes for PL-OOH is in the range of $30-50 \mu \mathrm{M}$ which falls within the range of estimated physiological concentrations of PL-OOH, particularly during the oxidative stress (Singhal et al., 1992). These findings further reaffirm that the $\alpha$-class GSTs play a key role in regulating lipid peroxidation by terminating the autocatalytic chain of lipid peroxidation. 


\section{ROLE OF GLUTATHIONE S-TRANSFERASES IN THE REGULATION OF}

\section{4-HYDROXYNONENAL LEVELS}

In addition to the cationic $\alpha$-class GSTs (GSTs A1-1, A2-2, and A3-3), a subgroup of the anionic $\alpha$-class GSTs present in human (hGST5.8) (Singhal et al., 1994a; 1994b), rat (rGSTA4-4) (Alin et al., 1985; Stenberg et al., 1992), and mouse (mGSTA4-4) (Medh et al., 1991; Zimniak et al., 1992; 1994) can utilize 4-HNE as the preferred substrate and conjugate it to GSH with high efficiency. In humans, at least two GST isoenzymes with high affinity for 4-HNE have been described. A hGST isoenzyme immunologically similar to mGSTA4-4 with higher specific activity towards 4-HNE was first described in our laboratory (Singhal et al,. 1994a; 1994b; 1995; 1999). This enzyme is temporarily designated as hGST5.8 (according to its pI value) since its complete primary structure is still not known and it has not been cloned yet perhaps due to its extremely low constitutive abundance in cDNA libraries (Cheng et al., 2001a). Another human enzyme hGSTA4-4 with high affinity for 4-HNE has been cloned (Hubatsch et al., 1998). Subsequent studies have shown that hGSTA4-4 and hGST5.8 are immunologically distinct not only from other human GSTs but also from each other and are expressed in a tissue specific manner (Cheng et al., 2001c). Both, hGST5.8 and mGSTA4-4, display much lower GPx activity towards PL-OOH as compared to that of hGSTA1-1 and hGSTA2-2 (Zimniak et al., 1994; Singhal et al., 1994a; 1994b). However, the catalytic efficiency of these enzymes for the conjugation of 4-HNE to GSH is higher than the efficiencies of most of the GST isoenzymes for xenobiotics. This observation along with their low $K_{\mathrm{m}}$ for 4 -HNE strongly suggest that these enzymes play an important role in the regulation of the intracellular levels of 4-HNE.

In vitro studies with cell lines strongly suggest that GSTsA4-4 and hGST5.8 are the ma- jor determinants of the intracellular concentrations of 4-HNE (Cheng et al., 1999; 2001a). Even though 4-HNE can be reduced by aldehyde dehydrogenase and aldose reductase (Hartley et al., 1995; Srivastava et al., 1995), majority of cellular 4-HNE is metabolized through its conjugation by reaction catalyzed by GSTs (Srivastava et al., 1998). Overexpression of mGSTA4-4 leads to a dramatic
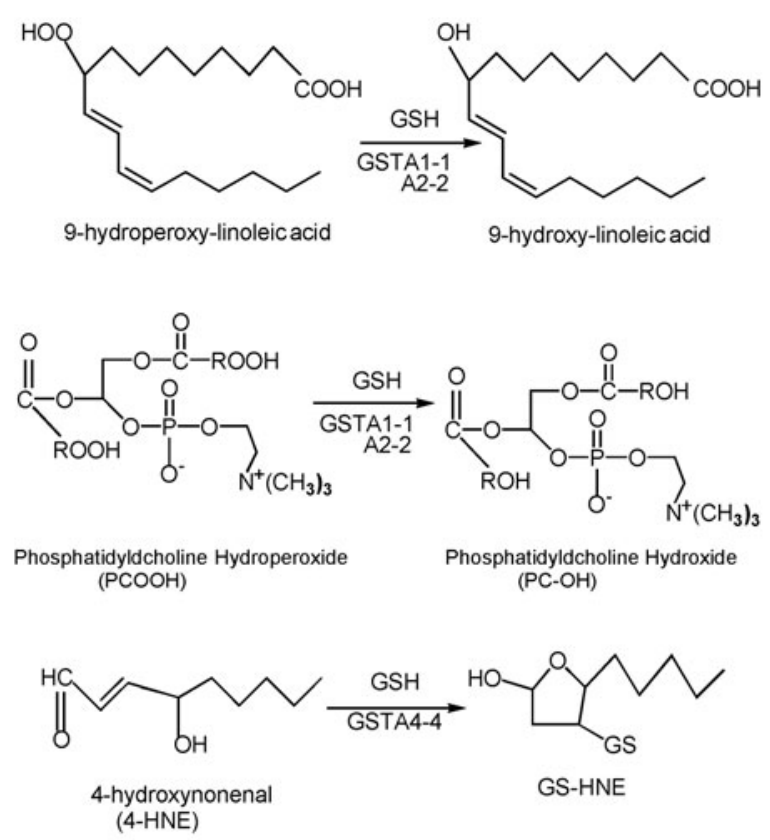

Figure 2. Lipid peroxidation products are substrates of GSTs.

decrease in the levels of 4-HNE in human erythroleukemia cells (Cheng et al., 1999) due to its conjugation to GSH. The conjugate of 4-HNE (GS-HNE) must be transported out of cells to sustain GST-mediated conjugation of 4-HNE because the conjugate inhibits GSTs. GS-HNE is transported from cells by ATP-dependent primary active transport similar to other GSH-conjugates (Awasthi et al., 1994; 1998a; 1998b; 2000). Our studies with various cell lines and erythrocytes indicate that in humans, majority (about 2/3) of GS-HNE transport is catalyzed by RLIP76 (Awasthi et al., 2000; 2002; Sharma et al., 2001; 2002), a previously described Ral binding protein (Jullien-Flores et al., 1995). These studies 
(Singhal et al., 2003, Awasthi et al., 2003a; 2003b) show that the multidrug resistance protein (MRP1) accounts for only about $1 / 3$ of GS-HNE transport which is consistent with reports that MRP1 also mediates transport of GS-HNE (Renes et al., 2000). We have shown that a coordinated action of GSTs and RLIP76 (Fig. 3) is the major determinant of 4-HNE

\section{Stress}

Heat, Chemical, Irradiations, etc.
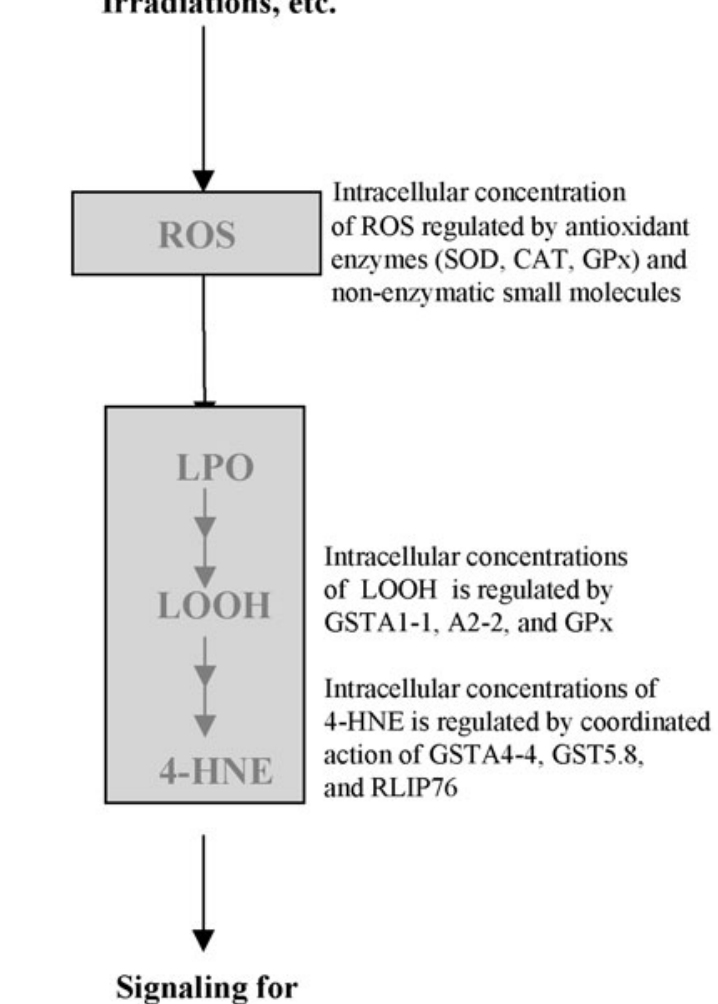

apoptosis, differentiation, proliferation, etc. determined by the intracellular levels of LPO

Figure 3. Lipid peroxidation and stress-mediated signaling.

concentration in cells. During oxidative stress, heat shock, or UV irradiation, which cause increased 4-HNE levels in cells, a rapid but transient induction of hGST5.8 and RLIP76 occurs, which strongly suggests that both these proteins play an important role in the regulation of the intracellular levels of 4-HNE (Cheng et al., 2001a). Cells with induced hGST5.8 and RLIP76, transport GS-HNE at a several fold higher rate as com- pared to the controls which further confirms the role of these proteins in regulations of cellular concentrations of 4-HNE. Manipulating the intracellular concentrations of these proteins has provided useful information on the role of 4-HNE in signaling (Cheng et al., 1999; 2001a; Yang et al., 2001) and some of these studies are discussed in detail later in this article.

\section{ROLE OF LIPID PEROXIDATION PRODUCTS IN SIGNALING}

4-HNE and LOOH have been extensively studied for their possible roles in signaling (see for review Esterbauer et al., 1991; Dianzani et al., 1999). Review of all these studies is beyond the scope of this article and only some of these studies which implicate LOOH and 4-HNE in signaling are reviewed briefly.

\section{Lipid hydroperoxides and signaling}

It has been shown that membrane PL-OOH can activate $\mathrm{PKC}$ activity, which in turn promotes cytosolic phospholipase $\mathrm{A}_{2} \quad\left(\mathrm{cPLA}_{2}\right)$ phosphorylation and its translocation to membrane, possibly through mitogen activated protein kinases (MAPK). Thus, PL-OOH can increase the hydrolytic activity of $\mathrm{cPLA}_{2}$ without marked changes in intracellular free $\mathrm{Ca}^{2+}$ concentration (Rashba-Step et al., 1997; Suzuki et al., 1997). PL-OOH can also stimulate the interleukin-1-induced nuclear factor kappa B $(\mathrm{NF} \kappa \mathrm{B})$ activation in a human endothelial cell line as suggested by studies showing that overexpression of GPx-4, which preferentially reduces $\mathrm{PL}-\mathrm{OOH}$, leads to the inhibition of the above signaling (Brigelius-Flohe et al., 1997). PL-OOH separated from oxidized low density lipoprotein shows platelet-activating factorlike activity, which can stimulate neutrophil adhesion and smooth muscle cell proliferation (Heery et al., 1995). Low levels of FA-OOH including 5-hydroperoxyeicosatetraenoic acid (5-HPETE) and 13S-hydroperoxy-9Z,11E-octa- 
decadienoic acid (13S-HPODE) are required for cyclooxygenase and 5- or 15-lipoxygenase activity (Schnurr et al., 1996; Foley, 2001). Yang et al. (2001; 2002a) have shown that $\mathrm{PL}-\mathrm{OOH}$ can induce apoptosis in human erythroleukemia (K562) and human lens epithelial (HLE B-3) cells through a sustained activation of stress activated protein kinase/ c-Jun N-terminal kinase (SAPK/JNK) and caspase 3 .

\section{4-Hydroxynonenal and signaling}

4-HNE, a relatively stable end product of lipid peroxidation, is a potent alkylating agent which can react with a variety of nucleophilic sites in DNA and protein, generating various types of adducts (Esterbauer et al., 1991). Its role in signaling mechanisms has been suggested for quite some time (Barrera et al., 1996). Lately, numerous studies from different laboratories using a variety of cell lines have shown that 4-HNE activates SAPK/JNK (Parola et al., 1998; Uchida et al., 1999; Cheng et al., 2001b), a member of MAPK family which is involved in apoptosis (Seger \& Krebs, 1995). In hepatic stellate cells, 4-HNE activates JNK through direct binding and not by phosphorylation (Parola et al., 1998), while in other cells, 4-HNE appears to activate JNK through the redox-sensitive MAPK kinase cascade (Uchida et al., 1999). It has been suggested that 4-HNE-induced JNK activation promotes its translocation in the nucleus where JNK-dependent phosphorylation of c-Jun and the transcription factor activator protein (AP-1) binding take place (Camandola et al., 2000; Cheng et al., 2001b), leading to the transcription of a number of genes having AP-1 consensus sequences in their promoter regions. JNK activation by 4 -HNE also leads to the activation of caspase 3 (Soh et al., 2000; Cheng et al., 2001b).

4-HNE has also been shown to modulate the expression of various genes, including PKC $\beta \mathrm{II}$, c-myc, procollagen type I, aldose reductase, c-myb, and transforming growth factor $\beta 1$ (Poli \& Schaur, 2000). Although the majority of studies show that 4-HNE is pro-apoptotic, it can also stimulate cell proliferation at relatively lower intracellular concentrations (Ruef et al., 1998; Cheng et al., 1999). In HL-60 cells, physiological concentration of 4-HNE inhibits proliferation and induces a granulocyte-like differentiation (Barrera et al., 1996). Several studies suggest that the intracellular concentration of 4-HNE may differentially affect the signal for proliferation, differentiation, and apoptosis (Cheng et al., 1999; 2001a; 2001b). A simplified version of the proposed role of lipid peroxidation products in stress mediated signaling is outlined in Fig. 4. The hypothesis stems from the studies

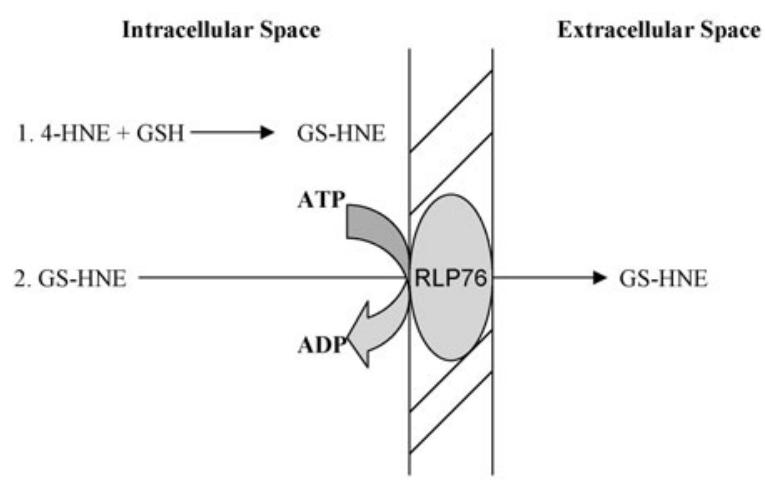

Figure 4. Regulation of 4-HNE concentration by coordinated action of GSTs and RLIP76.

1. Reaction catalyzed by hGST5.8 (Singhal et al., 1994), hGSTA4-4 (human) (Hubatsch et al.,1998), mGSTA4-4 (mouse) (Zimniak et al., 1994), and rGSTA4-4 (rat) (Stenberg et al., 1992). 2. ATP-dependent transport catalyzed by RLIP76 (Awasthi et al., 2000; Cheng et al., 2001a).

which suggest that both, PL-OOH and 4-HNE mediate cell cycle signaling. Perhaps stress mediated signaling for apoptosis is transduced through lipid peroxidation products because recent studies suggest apoptosis caused by UV, oxidative stress, and chemical agents can be modulated by manipulating the expression of GSTA1-1, GSTA2-2, GSTA4-4, hGST5.8, and RLIP76, which regulate the intracellular concentrations of $\mathrm{LOOH}$ and 
4-HNE (Cheng et al., 2001a; 2001b; Yang et al., 2001; 2002a).

\section{GLUTATHIONE $S$-TRANSFERASES CAN MODULATE ROS-INDUCED SIGNALING FOR APOPTOSIS BY CONTROLLING LIPID PEROXIDATION}

\section{Role of lipid hydroperoxides in signaling for apoptosis}

Studies in our laboratory (Yang et al., 2001) have shown that transfection of K562 cells with the $\alpha$-class GSTs, hGSTA1-1/A2-2 results in about 10-fold higher GPx activity towards PL-OOH, while the activities of other antioxidant enzymes such as CAT, SOD, peroxidase activity towards $\mathrm{H}_{2} \mathrm{O}_{2}$ remain unaltered. Intracellular lipid peroxidation under physiological conditions as well as under the conditions of oxidative stress is dramatically decreased in the transfected cells as compared to the empty vector transfected control or wild type cells. Upon treatment with $30 \mu \mathrm{M}$ $\mathrm{H}_{2} \mathrm{O}_{2}$, hGSTA2-2 transfected cells show a transient activation of JNK, which quickly returns to the basal levels. $\mathrm{H}_{2} \mathrm{O}_{2}$ does not cause caspase 3 activation under these conditions in the transfected cells and these cells do not undergo apoptosis. In contrast, the wild type and empty vector-transfected cells show a persistent activation of JNK and caspase 3 and these cells undergo apoptosis as measured by characteristic DNA laddering (Fig. 5). Since hGSTA1-1 and hGSTA2-2 display no detectable activity towards $\mathrm{H}_{2} \mathrm{O}_{2}$, this protective effect of GSTs against $\mathrm{H}_{2} \mathrm{O}_{2}$-mediated apoptosis must be exerted through their GPx activity and reduction of PL-OOH/FA-OOH. This is suggested by the studies showing that phosphatidylcholine hydroperoxide (PC-O$\mathrm{OH})$ treatment results in a marked apoptosis in the wild type and vector-transfected cells but the transfected cells are protected from PC-OOH mediated apoptosis (Fig. 5). These studies strongly suggest that at least a part of
$\mathrm{H}_{2} \mathrm{O}_{2}$-induced signaling for JNK, caspase 3 activation, and apoptosis must be transduced through PL-OOH or their downstream products, particularly, 4-HNE. Unpublished studies in our laboratory show that overexpression of hGSTA1-1 or hGSTA2-2 protects various cell types from UV-A induced apoptosis. Likewise, hGSTA1-1/hGSTA2-2 transfected cells are resistant to apoptosis caused by the presence of oxidative stress causing agents such as xanthine/xanthine oxidase, adriamycin, and naphthalene. HLE B-3 cells show a persistent activation of JNK and caspase and undergo apoptosis in the presence of naphthalene in medium. However, hGSTA1-1 transfected HLE B-3 cells neither show JNK or caspase activation nor undergo apoptosis under similar conditions of naphthalene treatment (Yang et al., 2002a). These studies suggest that lipid peroxidation products, $\mathrm{PL}-\mathrm{OOH}$ or their downstream products, are involved in ROS-mediated signaling for apoptosis. Furthermore, these studies provide crediable evidence that lipid peroxidation products may be a common factor in the mechanisms of the signaling for apoptosis by oxidative stress, chemical agents, and UV irradiation.

\section{Effect of 4-hydroxynonenal levels on signaling}

The role of 4-HNE in signaling has been examined in K562 cells transfected with mGSTA4 (Cheng et al., 1999). The transfected cells had about 5-fold higher GST activity toward 4-HNE as compared to the controls and 4-HNE content of the transfected cells (5.9 $\mathrm{pmol} / 5 \times 10^{7}$ cells) was found to be only about $10 \%$ of that observed in the empty vector transfected or wild types cells (62.9 $\mathrm{pmol} / 5 \times 10^{7}$ cells). Antioxidant enzymes (CAT, SOD, and GPx) were not affected by mGSTA4 transfection. Surprisingly, the mGSTA4 transfected cells had about 50\% higher growth rate as compared to the wild type or vector transfected cells suggesting that lowering the levels of 4-HNE in these cells 
promoted proliferation. Promotion of proliferation at low intracellular levels of $4-\mathrm{HNE}$ has also been observed in other cell lines. HLE B-3 cells transfected with hGSTA4-4 resulting in lower levels of intracellular 4-HNE grow at levels of 4-HNE has been observed at Ruef et al. (1998). Increasing concentrations of 4-HNE in the medium differentially affected the mGSTA4-transfected and empty vector-transfected cells. Exposure of $20 \mu \mathrm{M}$

A
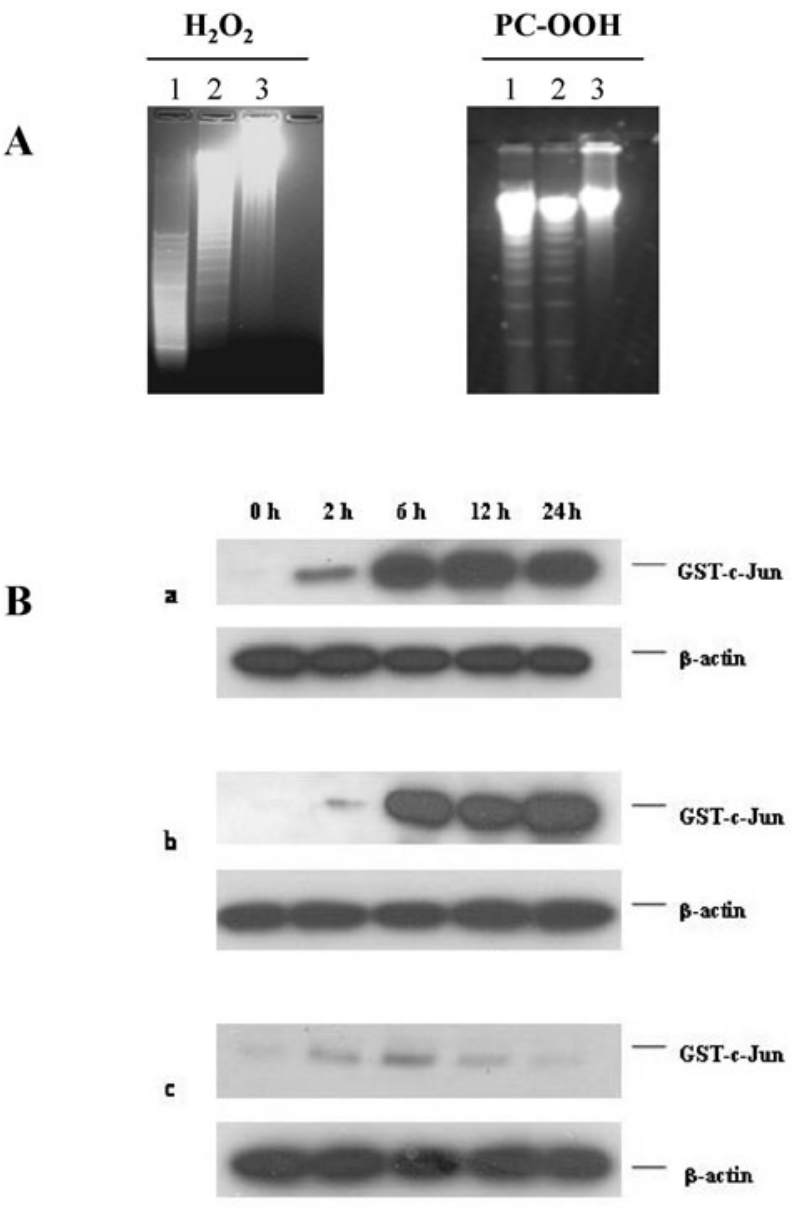

Figure 5. Effects of hGSTA2-2 over-expression on $\mathrm{H}_{2} \mathrm{O}_{2}$ induced apoptosis and JNK activation in K562 cells.

Panel A: wild-type, vector-transfected, and hGSTA2-transfected K562 cells were treated with $30 \mu \mathrm{M} \mathrm{H}_{2} \mathrm{O}_{2}$ for $48 \mathrm{~h}$ or $40 \mu \mathrm{M}$ PC-OOH for $8 \mathrm{~h}$ in RPMI complete medium. After the incubations, genomic DNA was extracted and electrophoresed on $2 \%$ agarose gel. Lanes 1, 2, 3 in all panels represent the wild-type, vector-transfected, and hGSTA2-transfected K562 cells, respectively. Apoptosis was examined by the appearance of characteristic DNA laddering. Panel B: cells were incubated with $30 \mu \mathrm{M} \mathrm{H}_{2} \mathrm{O}_{2}$ for the indicated times. Cell extracts containing $250 \mu \mathrm{g}$ proteins from the wild-type (a), vector-transfected (b), and hGSTA2-transfected (c) cells were incubated overnight with $2 \mu \mathrm{g}$ of GST-c-Jun (1-89) fusion protein. After extensive washing, the kinase reaction was performed in the presence of $100 \mu \mathrm{M}$ of cold ATP. Phosphorylation of c-Jun at Ser63 was detected by Western blot analysis using Phospho-c-Jun (Ser63) antibody. $\beta$-Actin expression was shown to confirm same amount of protein incubated with c-Jun (reproduced from Yang et al., 2001, with permission from Journal of Biological Chemistry).

a rate about $50 \%$ faster than the wild type or vector transfected cells (unpublished observations). Likewise, the promotion of proliferation of aortic smooth muscle cells at very low
4-HNE to the wild type or empty vector transfected K562 cells resulted in a marked erythroid differentiation while the cells over expressing mGSTA4-4 and having lower 
intracellular levels of 4-HNE did not undergo such differentiation suggesting a role of 4-HNE in signaling for differentiation. Exposure of the wild type or vector transfected K562 cells to even higher concentration of 4-HNE $(>20 \mu \mathrm{M})$ in the medium resulted in apoptosis while the cells transfected with mGSTA4 were resistant to apoptosis under these conditions. More importantly, the cells transfected with mGSTA4 also showed resistance to $\mathrm{H}_{2} \mathrm{O}_{2}$ induced apoptosis, which implied that the signaling for $\mathrm{H}_{2} \mathrm{O}_{2}$ induced apoptosis was conveyed through 4-HNE. Since the transfection with $m G S T A 4$ did not affect the antioxidant enzymes such as CAT, $\mathrm{GPx}, \mathrm{SOD}$, the apoptotic effect of $\mathrm{H}_{2} \mathrm{O}_{2}$ could be blocked by the over expression of mGSTA4 only if 4-HNE was directly involved in signaling. The protective effect of the induction of the 4-HNE metabolizing enzyme, hGST5.8 against oxidative stress mediated apoptosis is also observed in a variety of cell lines (e.g., HL-60, H69, HLE B-3, RPE, H-226) of human origin (Cheng et al., 2001a). These studies strongly support the idea of the involvement of 4-HNE in oxidative stress mediated signaling for apoptosis and that it is not limited to a specific cell type but appears to be a generalized phenomenon.

There is strong evidence that a sustained activation of c-Jun N-terminal kinase (JNK) precedes apoptosis (Uchida et al., 1999). It has been shown that the prolongation of TNF- $\alpha$ induced JNK activation by incubating the cells with TNF- $\alpha$ in the presence of cycloheximide, actinomycin $\mathrm{D}$, or orthovanadate leads to apoptosis. A sustained activation of JNK achieved by inhibiting the expression of MKP-1, a dual specific phosphatase that inactivates JNK, has been shown to potentiate TNF- $\alpha$ induced apoptosis (Guo et al., 1998). A sustained activation of JNK is also observed in $\mathrm{H}_{2} \mathrm{O}_{2}$-induced apoptosis in K562 and HL-60 cells and these cells can be protected from apoptosis by blocking JNK activation (Cheng et al., 2001a; 2001b). Studies in our laboratory suggest a specific role of 4 -HNE in the activa- tion of JNK and caspase -3 in several cell lines of diverse origin. We have shown that the wild type or empty vector transfected HL-60 cells undergo apoptosis within $2 \mathrm{~h}$ when $20 \mu \mathrm{M}$ 4-HNE is included in the medium. Cells transfected with mGSTA4 having an enhanced capacity to metabolize 4-HNE leading to reduced intracellular levels of 4-HNE do not undergo apoptosis even after a prolonged period of exposure with $20 \mu \mathrm{M} 4$-HNE treatment. 4-HNE induces apoptosis in the wild type or vector-transfected cells which is preceded by a sustained activation of JNK and an increase in AP-1 binding within $2 \mathrm{~h}$. In mGSTA4-transfected cells, these effects of 4-HNE are significantly delayed which strongly suggests a role of 4-HNE in these processes. 4-HNE treated wild type cells show caspase -3 activation within $2 \mathrm{~h}$ while a detectable activation of caspase -3 is seen in mGSTA4-transfected cells only after $8 \mathrm{~h}$. Together, these studies strongly suggest a key role of 4-HNE in the events upstream to the activation of JNK and caspases.

\section{ROLE OF RLIP76 AND hGST5.8 IN REGULATION OF 4-HYDROXY- NONENAL LEVELS AND STRESS-MEDIATED SIGNALING}

If 4-HNE is involved in stress mediated signaling for apoptosis, lipid peroxidation and consequently 4-HNE formation may be enhanced in stressed cells. Many of the agents that induce apoptosis cause oxidative stress and subsequent lipid peroxidation and apoptosis subsequent to $\mathrm{H}_{2} \mathrm{O}_{2}$, UV, or drug (e.g. doxorubicin) exposure is usually accompanied with lipid peroxidation. Cells exposed to a transient and mild heat or oxidative stress show an induction of the mechanisms responsible for maintaining the intracellular levels of 4-HNE (Cheng et al., 2001a). Various human cell lines of diverse origin when exposed to either a mild heat, oxidative stress, or UV-A show an increased formation of 
4-HNE. Apoptosis is not observed under such mild stress conditions and the initial adaptive response of these cells includes a rapid but transient induction of hGST5.8 (the enzyme catalyzing the formation of the glutathione conjugate of 4-HNE) and RLIP76 (which catalyzes ATP dependent transport of GS-HNE) even prior to any noticeable induction of HSP70 or other antioxidant enzymes. This suggests that the maintenance of the basal "physiologic" levels of $4-\mathrm{HNE}$ is crucial to cells. The cells exposed to mild stress initially show a transient increase in 4-HNE levels and activation of JNK both of which quickly re- than that observed in controls. The stress preconditioned cells are relatively more resistant to $\mathrm{H}_{2} \mathrm{O}_{2}$, oxidative stress, or 4-HNE induced JNK activation, AP-1 DNA binding, caspase -3 activation and eventual apoptosis as compared to controls (Cheng et al., 2001a). Our unpublished studies show that control K562 cells undergo apoptosis when irradiated with UV-A for $30 \mathrm{~min}$. In contrast, the cells exposed to UV-A irradiation for $5 \mathrm{~min}$ and allowed to rest for $2 \mathrm{~h}$ show induction of RLIP76 and hGST5.8 and acquire relative resistance to UV-A induced apoptosis as compared to the control cells (Fig. 6). Likewise, cells precondi-
A
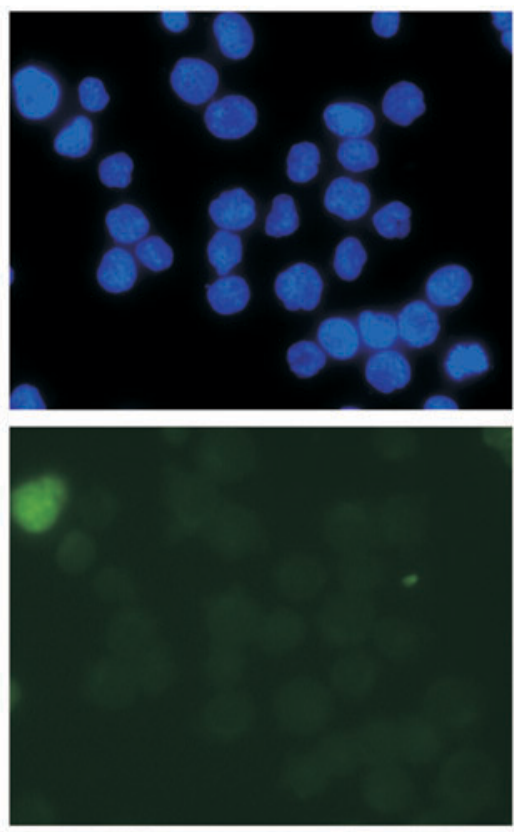

B
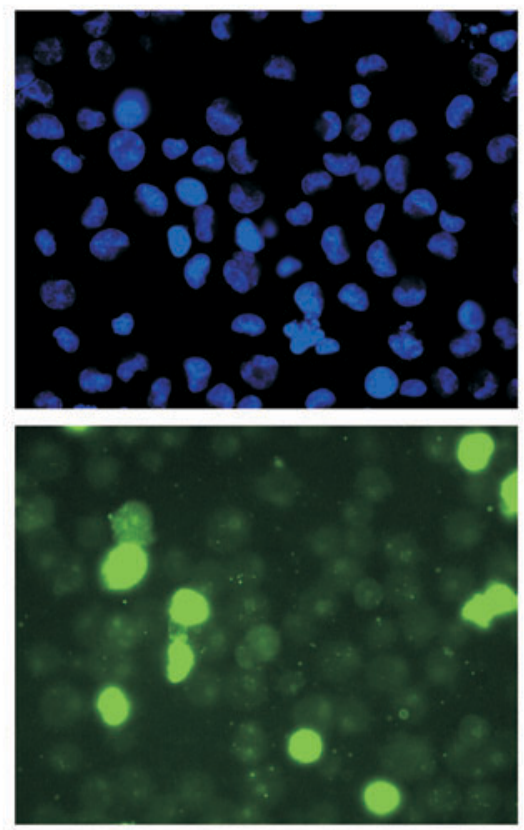

C
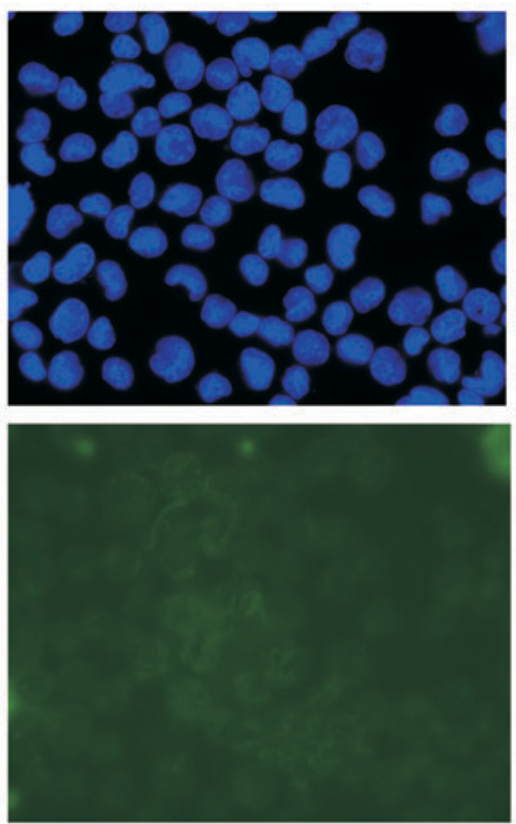

Figure 6. Effects of UV-A preconditioning on apoptosis induced by further UV-A irradiation.

K562 cells were irradiated with UV-A ( $365 \mathrm{~nm}$ ) for $5 \mathrm{~min}$ at $3 \mathrm{~mW} / \mathrm{cm}^{2}$ and were allowed to rest for $2 \mathrm{~h}$. After preconditioning, these cells were exposed to $30 \mathrm{~min}$ UV-A and the activation of caspases was examined by incubating with $10 \mu \mathrm{M}$ of CaspACE FITC-VAD-FMK in situ marker (Promega). The slides was mounted with mounting medium containing DAPI $(1.5 \mu \mathrm{g} / \mathrm{ml})$ and observed under fluorescent microscopy (Olympus, Japan). All the pictures were taken at $\times 400$ magnification. Panel A: control cells without any treatment; panel B: control cells irradiated for 30 min UVA; panel C: 5-min UV-A preconditioned cells irradiated for $30 \mathrm{~min}$. All the upper slides were stained with DAPI and all the lower slides were stained with FITC.

turn to basal levels. The stress preconditioned cells with induced hGST5.8 and RLIP76 can exclude intracellular 4-HNE by forming and transporting its glutathione conjugate (GS$\mathrm{HNE}$ ) out of cells at a rate several times faster tioned with mild UV-A exposure acquire resistance to apoptosis due to oxidative stress caused by including xanthine/xanthine oxidase in the medium. This resistance of stress-preconditioned cells to $\mathrm{H}_{2} \mathrm{O}_{2}$, xanthine/ 
xanthine oxidase, UV-A, or 4-HNE induced apoptosis correlates with their ability to metabolize and extrude GS-HNE at an accelerated rate as compared to the control cells. These results indicate that accelerated exclusion of 4-HNE from cells provides protection against $\mathrm{H}_{2} \mathrm{O}_{2}$, UV-A, and 4-HNE induced apoptosis and strongly suggest that a role of 4-HNE in stress mediated signaling for apoptosis.

If the stress preconditioned cells acquired resistance to 4-HNE and oxidative stress induced apoptosis by accelerated elimination of 4-HNE from cells through an increased formation and transport of GS-HNE, one would expect that this resistance could be overcome by blocking the transport of GS-HNE. Consistent with this expectation, the stress preconditioned cells can be made sensitive to $\mathrm{H}_{2} \mathrm{O}_{2}$ and 4-HNE mediated apoptosis by coating the cells with anti-RLIP76 IgG which blocks the transport of GS-HNE. Coating with preimmune IgG has no effect on GS-HNE transport and the stress-preconditioned cells remain resistant to $\mathrm{H}_{2} \mathrm{O}_{2}$ and 4-HNE mediated apoptosis and the efflux of GS-HNE from cells is not affected. However, coating the stress preconditioned cells with anti-RLIP76 IgG results in blockage of GS-HNE efflux and the cells undergo apoptosis when treated with 4-HNE or $\mathrm{H}_{2} \mathrm{O}_{2}$ the (Cheng et al., 2001a). These results provide strong evidence that 4-HNE mediates signaling for apoptosis in cells stressed with oxidants or heat. More importantly, these results also demonstrate that RLIP76 mediates the transport of GS-HNE and is one of the major determinants for intracellular concentration of 4-HNE. This is in contrast to earlier suggestions that MRP1 is the major (Pulaski et al., 1996) efflux pump for GSH-conjugates of endo- and exogenous electrophiles (Ishikawa, 1992). Further studies are needed to elucidate the role of various transporters which catalyze the ATP-dependent transport of GSH-conjugates.

The maintenance of the intracellular concentration of 4-HNE appears to be crucial for cell cycle signaling. Our studies suggest that cells respond to stress by inducing mechanisms for elimination of the excess 4-HNE formed due to stress and this response is even quicker than the induction of heat shock proteins and antioxidant enzymes. Even a slight increase in 4-HNE levels influences cell cycle signaling. Exposure of cells to $42^{\circ} \mathrm{C}$ for $30 \mathrm{~min}, 50 \mu \mathrm{M}$ $\mathrm{H}_{2} \mathrm{O}_{2}$ for $20 \mathrm{~min}$, or UV-A exposure for $5 \mathrm{~min}$, results only in a $50 \%$ increase in the steady state levels of 4-HNE concentrations above its basal levels. Yet there is transient activation of JNK that quickly subsides as the cells acquire the capacity to exclude 4-HNE at accelerated rates and bring 4-HNE concentrations to basal "physiologic" levels. These studies suggest that there is a narrow window of the basal levels of 4-HNE, which is tightly controlled by factors facilitating its metabolism and exclusion from cells. In case of a sustained stress and over production of 4-HNE the protective functions of GST5.8 and RLIP76 are overwhelmed, the intracellular concentrations of 4-HNE rise, and the cell in desperation calls for death signal. At low 4-HNE concentrations cells (at least some type, e.g., aortic smooth muscle, and K562 erythroleukemia cells) show proliferation. It is possible that there is a narrow range of "physiological" 4-HNE concentration within the cells. The cells tend to undergo differentiation, apoptosis when 4-HNE concentrations rise above this range. On the other hand, at 4-HNE concentrations below this range, the cells tend to proliferate. This idea is supported by unpublished studies in our laboratory which show that transfection of HLE B-3 cells with hGSTA4 results in lower 4-HNE concentrations and a faster growth rate of these cells and that it is accompanied with the activation of ERK which is involved in cell proliferation. This intriguing hypothesis on the role of 4 -HNE in regulating cell cycle signaling needs substantiation through further studies. Observed resistance to oxidative stress of the cells preconditioned with mild transient stress raises some interesting questions. Can the beneficial effects of 
exercise or that of ancient yogic practices such as Pranayam (controlled deep breathing) be attributed to mild oxidative stress? Likewise, can the reported beneficial effects of various Chinese and Indian herbal medicines be attributed to mild oxidative stress due to the metabolism of their constituents by cytochrome P-450 system? It may be worthwhile to explore these possibilities.

\section{R E F R E N C E S}

Acworth IN, McCabe DR, Maher TJ. (1997) The analysis of free radicals, their reaction products, and antioxidants. In Oxidants, Antioxidants, and Free Radicals. Baskin SI, Salem H, eds, pp 23-77. Taylor \& Francis, Washington, DC.

Alin P, Danielson UH, Mannervik B. (1985) 4-Hydroxyalk-2-enals are substrates for glutathione transferase. FEBS Lett.; 179: 267-70.

Ames BN, Shigenaga MK, Hagen TM. (1993) Oxidants, antioxidants, and the degenerative diseases of aging. Proc Natl Acad Sci U S A.; 90: $7915-22$.

Awasthi YC, Beutler E, Srivastava SK. (1975) Purification and properties of human erythrocyte glutathione peroxidase. J Biol Chem.; 250: 5144-9.

Awasthi YC, Dao DD, Saneto RP. (1980) Interrelationship between anionic and cationic forms of glutathione $S$-transferases of human liver. Biochem J.; 191: 1-10.

Awasthi S, Singhal SS, Srivastava SK, Zimniak P, Bajpai KK, Saxena M, Sharma R, Ziller SA 3rd, Frenkel EP, Singh SV, He NG, Awasthi YC. (1994) Adenosine triphosphate-dependent transport of doxorubicin, daunomycin, and vinblastine in human tissues by a mechanism distinct from the P-glycoprotein. J Clin Invest.; 93: 958-65.

Awasthi S, Singhal SS, Srivastava SK, Torman RT, Zimniak P, Bandorowicz-Pikula J, Singh SV, Piper JT, Awasthi YC, Pikula S. (1998a) ATP-Dependent human erythrocyte glutathione-conjugate transporter. I. Purification, photoaffinity labeling, and kinetic characteristics of ATPase activity. Biochemistry.; 37: 5231-8.

Awasthi S, Singhal SS, Pikula S, Piper JT, Srivastava SK, Torman RT, Bandorowicz-Pikula J, Lin JT, Singh SV, Zimniak P, Awasthi YC. (1998b)

ATP-Dependent human erythrocyte glutathione-conjugate transporter. II. Functional reconstitution of transport activity. Biochemistry.; 37: 5239-48.

Awasthi S, Cheng JZ, Singhal SS, Saini MK, Pandya U, Pikula S, Bandorowicz-Pikula J, Singh SV, Zimniak P, Awasthi YC. (2000) Novel function of human RLIP76:

ATP-dependent transport of glutathione conjugates and doxorubicin. Biochemistry.; 39: 9327-34.

Awasthi S, Cheng JZ, Singhal SS, Pandya U, Sharma R, Singh SV, Zimniak P, Awasthi YC. (2001) Functional reassembly of ATP-dependent xenobiotic transport by the $\mathrm{N}$ - and C-terminal domains of RLIP76 and identification of ATP binding sequences. Biochemistry.; 40: 4159-68.

Awasthi S, Sharma R, Singhal SS, Zimniak P, Awasthi YC. (2002) RLIP76, a novel transporter catalyzing ATP-dependent efflux of xenobiotics. Drug Metab Dispos.; 30: 1300-10.

Awasthi S, Singhal SS, Singhal J, Cheng J, Zimniak P, Awasthi YC. (2003a) Role of RLIP76 in lung cancer doxorubicin resistance: II. Doxorubicin transport in lung cancer by RLIP76. Int J Oncol.; 22: 713-20.

Awasthi S, Singhal SS, Singhal J, Yang Y, Zimniak P, Awasthi YC. (2003b) Role of RLIP76 in lung cancer doxorubicin resistance: III. Anti-RLIP76 antibodies trigger apoptosis in lung cancer cells and synergistically increase doxorubicin cytotoxicity. Int $J$ Oncol.; 22: 721-32.

Barrera G, Pizzimenti S, Serra A, Ferretti C, Fazio VM, Saglio G, Dianzani MU. (1996) 4-Hydroxynonenal specifically inhibits c-myb but does not affect c-fos expressions in HL-60 
cells. Biochem Biophys Res Commun.; 227: 589-93.

Beckman JS, Koppenol WH. (1996) Nitric oxide, superoxide, and peroxynitrite: the good, the bad, and ugly. Am J Physiol.; 271: C1424-37.

Bhuyan KC, Bhuyan DK, Podos SM. (1986) Lipid peroxidation in cataract of the human. Life Sci.; 38: 1463-71.

Brigelius-Flohe R, Friedrichs B, Maurer S, Schultz M, Streicher R. (1997) Interleukin-1-induced nuclear factor kappa B activation is inhibited by overexpression of phospholipid hydroperoxide glutathione peroxidase in a human endothelial cell line. Biochem J.; 328: 199-203.

Camandola S, Poli G, Mattson MP. (2000) The lipid peroxidation product 4-hydroxy-2,3-nonenal increases AP-1-binding activity through caspase activation in neurons. J Neurochem.; 74: 159-68.

Chen Q, Ames BN. (1994) Senescence-like growth arrest induced by hydrogen peroxide in human diploid fibroblast F65 cells. Proc Natl Acad Sci U S A.; 91: 4130-4.

Cheng JZ, Singhal SS, Saini M, Singhal J, Piper JT, Van Kuijk FJ, Zimniak P, Awasthi YC, Awasthi S. (1999) Effects of mGST A4 transfection on 4-hydroxynonenal-mediated apoptosis and differentiation of K562 human erythroleukemia cells. Arch Biochem Biophys.; 372: 29-36.

Cheng JZ, Sharma R, Yang Y, Singhal SS, Sharma A, Saini MK, Singh SV, Zimniak P, Awasthi S, Awasthi YC. (2001a) Accelerated metabolism and exclusion of 4-hydroxynonenal through induction of RLIP76 and hGST5.8 is an early adaptive response of cells to heat and oxidative stress. $J$ Biol Chem.; 276: 41213-23.

Cheng JZ, Singhal SS, Sharma A, Saini M, Yang Y, Awasthi S, Zimniak P, Awasthi YC. (2001b) Transfection of mGSTA4 in HL-60 cells protects against 4-hydroxynonenal-induced apoptosis by inhibiting JNK-mediated signaling. Arch Biochem Biophys.; 392: 197-207.
Cheng JZ, Yang Y, Singh SP, Singhal SS, Awasthi S, Pan SS, Singh SV, Zimniak P, Awasthi YC. (2001c) Two distinct 4-hydroxynonenal metabolizing glutathione $S$-transferase isozymes are differentially expressed in human tissues. Biochm Biophys Res Commun.; 282: 1268-74.

Chu FF, Doroshow JH, Esworthy RS. (1993) Expression, characterization, and tissue distribution of a new cellular selenium-dependent glutathione peroxidase, GSHPx-GI. J Biol Chem.; 268: 2571-6.

Craven PA, Pfanstiel J, DeRubertis FR. (1986) Role of reactive oxygen in bile salt stimulation of colonic epithelial proliferation. J Clin Invest.; 77: 850-9.

Crawford DR, Schools GP, Davies KJ. (1996) Oxidant-inducible adapt15 RNA is associated with growth arrest- and DNA damage-inducible gadd153 and gadd45. Arch Biochem Biophys.; 329: 137-44.

Davies KJ. (2000) Oxidative stress, antioxidant defenses, and damage removal, repair, and replacement systems. IUBMB Life.; 50: 279-89.

Dianzani MU, Barrera G, Parola M. (1999) 4-Hydroxy-2,3-nonenal as a signal for cell function and differentiation. Acta Biochim Polon.; 46: 61-75.

Esterbauer H, Schaur RJ, Zollner H. (1991) Chemistry and biochemistry of 4-hydroxynonenal, malonaldehyde and related aldehydes. Free Radic Biol Med.; 11: 81-128.

Foley TD. (2001) The cyclooxygenase hydroperoxide product $\mathrm{PGG}_{2}$ activates synaptic nitric oxide synthase: a possible antioxidant response to membrane lipid peroxidation. Biochem Biophys Res Commun.; 286: $235-8$.

Guo YL, Kang B, Williamson JR. (1998) Inhibition of the expression of mitogen-activated protein phosphatase-1 potentiates apoptosis induced by tumor necrosis factor-alpha in rat mesangial cells. J Biol Chem.; 273: 10362-6.

Hartley DP, Ruth JA, Petersen DR. (1995) The hepatocellular metabolism of 
4-hydroxynonenal by alcohol dehydrogenase, aldehyde dehydrogenase, and glutathione S-transferase. Arch Biochem Biophys.; 316: 197-205.

Hayes JD, Pulford DJ. (1995) The glutathione S-transferase supergene family: regulation of GST and the contribution of the isoenzymes to cancer chemoprotection and drug resistance. Crit Rev Biochem Mol Biol.; 30: 445-600.

Heery JM, Kozak M, Stafforini DM, Jones DA, Zimmerman GA, McIntyre TM, Prescott SM. (1995) Oxidatively modified LDL contains phospholipids with platelet-activating factor-like activity and stimulates the growth of smooth muscle cells. J Clin Invest.; 96: 2322-30.

Hiratsuka A, Yamane H, Yamazaki S, Ozawa N, Watabe T. (1997) Subunit Ya-specific glutathione peroxidase activity toward cholesterol 7-hydroperoxides of glutathione S-transferases in cytosols from rat liver and skin. J Biol Chem.; 272: 4763-9.

Hubatsch I, Ridderstrom M, Mannervik B. (1998) Human glutathione S-transferase A4-4: an alpha class enzyme with high specificity for 4-hydroxynoneal and other genototoxic products of lipid peroxidation. Biochem J. ; 330: 175-9.

Ikebuchi Y, Masumoto N, Tasaka K, Koike K, Kasahara K, Miyake A, Tanizawa O. (1991) Superoxide anion increases intracellular $\mathrm{pH}$, intracellular free calcium, and arachidonate release in human amnion cells. J Biol Chem.; 266: 13233-7.

Ishikawa T. (1992) The ATP-dependent glutathione S-conjugate export pump. Trends Biochem Sci.; 17: 463-8.

Jullien-Flores V, Dorseuil O, Romero F, Letourneur F, Saragosti S, Berger R, Tavitian A, Gacon G, Camonis JH. (1995) Bridging Ral GTPase to Rho pathways. RLIP76, a Ral effector with CDC42/Rac GTPase-activating protein activity. $J$ Biol Chem.; 270: 22473-7.

Kruman I, Bruce-Keller AJ, Bredesen D, Waeg G, Mattson MP. (1997) Evidence that 4-hydroxynonenal mediates oxidative stress-induced neuronal apoptosis. $J$ Neurosci.; 17: 5089-100.

Lawrence RA, Burk RF. (1976) Glutathione peroxidase activity in selenium-deficient rat liver. Biochem Biophys Res Commun.; 71: 952-8.

Leonarduzzi G, Arkan MC, Basaga H, Chiarpotto E, Sevanian A, Poli G. (2000) Lipid oxidation products in cell signaling. Free Radic Biol Med.; 28: 1370-8.

Mannervik B, Danielson UH. (1988) Glutathione transferases - structure and catalytic activity. CRC Crit Rev Biochem.; 23: 283-337.

Mannervik B, Awasthi YC, Board PG, Hayes JD, Di Ilio C, Ketterer B, Listowsky I, Morgenstern R, Muramatsu M, Pearson WR, Pickett, CB, Sato K, Widersten M, Wolf CR. (1992) Nomenclature for human glutathione transferases. Biochem J.; 282: 305-6.

Markesbery WR, Lovell MA. (1997) Four-hydroxynonenal, a product of lipid peroxidation, is increased in the brain in Alzheimer's disease. Neurobiol Aging.; 19: 33-6.

Medh RD, Saxena M, Singhal SS, Ahmad H, Awasthi YC. (1991) Characterization of a novel glutathione S-transferase isoenzyme from mouse lung and liver having structural similarity to rat glutathione S-transferase 8-8. Biochem J.; 278: 793-9.

Murrell GA, Francis MJ, Bromley L. (1990) Modulation of fibroblast proliferation by oxygen free radicals. Biochem J.; 265: 659-65.

Parola M, Robino G, Marra F, Pinzani M, Bellomo G, Leonarduzzi G, Chiarugi P, Camandola S, Poli G, Waeg G, Gentilini P, Dianzani MU. (1998) HNE interacts directly with JNK isoforms in human hepatic stellate cells. J Clin Invest.; 102: 1942-50.

Poli G, Schaur RJ. (2000) 4-Hydroxynonenal in the pathomechanisms of oxidative stress. IUBMB Life.; 50: 315-21.

Prohaska JR, Ganther HE. (1976) Glutathione peroxidase activity of glutathione-S-transferases purified from rat liver. Biochem Biophys Res Commun.; 76: 437-45. 
Pulaski L, Jedlitschky G, Leier I, Buchholz U, Keppler D. (1996) Identification of the multidrug-resistance protein (MRP) as the glutathione-S-conjugate export pump of erythrocytes. Eur J Biochem.; 241: 644-8.

Rashba-Step J, Tatoyan A, Duncan R, Ann D, Pushpa-Rehka TR, Sevanian A. (1997) Phospholipid peroxidation induces cytosolic phospholipase $\mathrm{A}_{2}$ activity: membrane effects versus enzyme phosphorylation. Arch Biochem Biophys.; 343: 44-54.

Renes J, de Vries EE, Hooiveld GJ, Krikken I, Jansen PL, Muller M. (2000) Multidrug resistance protein MRP1 protects against the toxicity of the major lipid peroxidation product 4-hydroxynonenal. Biochem J.; 350: 555-61.

Ruef J, Rao GN, Li F, Bode C, Patterson C, Bhatnagar A, Runge MS. (1998) Induction of rat aortic smooth muscle cell growth by the lipid peroxidation product 4-hydroxy-2-nonenal. Circulation.; 97: 1071-8.

Schnurr K, Belkner J, Ursini F, Schewe T, Kuhn H. (1996) The selenoenzyme phospholipid hydroperoxide glutathione peroxidase controls the activity of the 15-lipoxygenase with complex substrates and preserves the specificity of the oxygenation products. $J$ Biol Chem.; 271: 4653-8.

Seger R, Krebs EG. (1995). The MAPK signaling cascade. FASEB J.; 9: 726-35.

Sharma R., Singhal SS, Cheng JZ, Yang Y, Sharma A, Zimniak P, Awasthi S, Awasthi YC. (2001) RLIP76 is the major ATP-dependent transporter of glutathione-conjugates and doxorubicin in human erythrocytes. Arch Biochem Biophys.; 391: 71-9.

Sharma R, Sharma A, Yang Y, Awasthi S, Singhal SS, Zimniak P, Awasthi YC. (2002) Functional reconstitution of Ral-binding GTPase activating protein, RLIP76, in proteoliposomes catalyzing ATP-dependent transport of glutathione conjugate of 4-hydroxynonenal. Acta Biochim Polon.; 49: 693-701.

Sies H. (1985) Oxidative stress: introductory remarks. In Oxidative Stress. Sies H, ed, pp 1-8. Academic Press, London.
Singhal SS, Saxena M, Ahmad H, Awasthi S, Haque AK, Awasthi YC. (1992) Glutathione S-transferases of human lung: characterization and evaluation of the protective role of the alpha-class isozymes against lipid peroxidation. Arch Biochem Biophys.; 299: $232-41$.

Singhal SS, Zimniak P, Sharma R, Srivastava SK, Awasthi S, Awasthi YC. (1994a) A novel glutathione S-transferase isozyme similar to GST 8-8 of rat and mGSTA4-4 (GST 5.7) of mouse is selectively expressed in human tissues. Biochim Biophys Acta.; 1204: 279-86.

Singhal SS, Zimniak P, Awasthi S, Piper JT, He NG, Teng JI, Petersen DR, Awasthi YC. (1994b) Several closely related glutathione S-transferase isozymes catalyzing conjugation of 4-hydroxynonenal are differentially expressed in human tissues. Arch Biochem Biophys.; 311: 242-50.

Singhal SS, Awasthi S, Srivastava SK, Zimniak P, Ansari NH, Awasthi YC. (1995) Novel human ocular glutathione S-transferases with high activity toward 4-hydroxynonenal. Invest Ophthalmol Vis Sci.; 36: 142-50.

Singhal SS, Godley BF, Chandra A, Pandya U, Jin GF, Saini MK, Awasthi S, Awasthi YC. (1999) Induction of glutathione S-transferase hGST 5.8 is an early response to oxidative stress in RPE cells. Invest Ophthalmol Vis Sci.; 40: 2652-9.

Singhal SS, Singhal J, Sharma R, Singh SV, Zimniak P, Awasthi YC, Awasthi S. (2003) Role of RLIP76 in lung cancer doxorubicin resistance: I. The ATPase activity of RLIP76 correlates with doxorubicin and 4-hydroxynonenal resistance in lung cancer cells. Int J Oncol.; 22: 365-75.

Soh Y, Jeong KS, Lee IJ, Bae MA, Kim YC, Song BJ. (2000) Selective activation of the c-Jun N-terminal protein kinase pathway during 4-hydroxynonenal-induced apoptosis of PC12 cells. Mol Pharmacol.; 58: 535-41.

Srivastava S, Chandra A, Bhatnagar A, Srivastava SK, Ansari NH. (1995) Lipid peroxidation product, 4-hydroxynonenal and its conjugate with GSH are excellent sub- 
strates of bovine lens aldose reductase. Biochem Biophys Res Commun.; 217: 741-6.

Srivastava S, Chandra A, Wang LF, Seifert WE Jr, DaGue BB, Ansari NH, Srivastava SK, Bhatnagar A. (1998) Metabolism of the lipid peroxidation product, 4-hydroxy-trans-2-nonenal, in isolated perfused rat heart. J Biol Chem.; 273: 10893-900.

Stenberg G, Ridderstrom M, Engstrom A, Pemble SE, Mannervik B. (1992) Cloning and heterologous expression of cDNA encoding class alpha rat glutathione transferase 8-8, an enzyme with high catalytic activity towards genotoxic $\alpha, \beta$-unsaturated carbonyl compounds. Biochem J.; 284: 313-9.

Suzuki YJ, Forman HJ, Sevanian A. (1997) Oxidants as stimulators of signal transduction. Free Radic Biol Med.; 22: 269-85.

Takahashi K, Avissar N, Whitin J, Cohen H. (1987) Purification and characterization of human plasma glutathione peroxidase: a selenoglycoprotein distinct from the known cellular enzyme. Arch Biochem Biophys.; 256: 677-86.

Tan KH, Meyer DJ, Belin J, Ketterer B. (1984) Inhibition of microsomal lipid peroxidation by glutathione and glutathione transferases B and AA. Role of endogenous phospholipase $\mathrm{A}_{2}$. Biochem J.; 220: 243-52.

Thomas JP, Maiorino M, Ursini F, Girotti AW. (1990) Protective action of phospholipid hydroperoxide glutathione peroxidase against membrane-damaging lipid peroxidation. In situ reduction of phospholipid and cholesterol hydroperoxides. J Biol Chem.; 265: 454-61.

Uchida K, Shiraishi M, Naito Y, Torii Y, Nakamura Y, Osawa T. (1999) Activation of stress signaling pathways by the end product of lipid peroxidation. 4-Hydroxy-2-nonenal is a potential inducer of intracellular peroxide production. J Biol Chem.; 274: 2234-42.

Ursini F, Maiorino M, Gregolin C. (1985) The selenoenzyme phospholipid hydroperoxide glutathione peroxidase. Biochim Biophys Acta.; 839: 62-70.
Witztum JL. (1994) The oxidation hypothesis of atherosclerosis. Lancet.; 344: 793-5.

Yang Y, Cheng JZ, Singhal SS, Saini M, Pandya U, Awasthi S, Awasthi YC. (2001) Role of glutathione $S$-transferases in protection against lipid peroxidation. Overexpression of hGSTA2-2 in K562 cells protects against hydrogen peroxide-induced apoptosis and inhibits JNK and caspase 3 activation. $J$ Biol Chem.; 276: 19220-30.

Yang Y, Sharma R, Cheng JZ, Saini MK, Ansari NH, Andley UP, Awasthi S, Awasthi YC. (2002a). Transfection of HLE B-3 cells with hGSTA1 or hGSTA2 protects against hydrogen peroxide and naphthalene induced lipid peroxidation and apoptosis. Invest Ophthalmol Vis Sci.; 43: 434-45.

Yang Y, Sharma R, Zimniak P, Awasthi YC. (2002b) Role of alpha class glutathione $S$-transferases as antioxidant enzymes in rodent tissues. Toxicol Appl Pharmacol.; 182: 105- 15 .

Yoritaka A, Hattori N, Uchida K, Tanaka M, Stadtman ER, Mizuno Y. (1996)

Immunohistochemical detection of 4-hydroxynonenal protein adducts in Parkinson disease. Proc Natl Acad Sci U S A.; 93: 2696-701.

Zhao T, Singhal SS, Piper JT, Cheng JZ, Pandya U, Clark-Wronski J, Awasthi S, Awasthi YC. (1999) The role of human glutathione $S$-transferases hGSTA1-1 and hGSTA2-2 in protection against oxidative stress. Arch Biochem Biophys.; 367: 216-24.

Zimniak P, Eckles MA, Saxena M, Awasthi YC. (1992) A subgroup of class alpha glutathione $S$-transferases.Cloning of cDNA for mouse lung glutathione $S$-transferase GST 5.7. FEBS Lett.; 313: 173-6.

Zimniak P, Singhal SS, Srivastava SK, Awasthi S, Sharma R, Hayden JB, Awasthi YC. (1994) Estimation of genomic complexity, heterologous expression, and enzymatic characterization of mouse glutathione $S$-transferase mGSTA4-4 (GST 5.7). J Biol Chem.; 269: 992-1000. 